УДК 69.059.28/63-049.5

DOI: 10.30838/J.BPSACEA.2312.290818.70.94

\title{
SAFETYINCREASING DURING ELIMINATION OF CONSEQUENCES OF DAMAGES AND OPTION OF THE MOST EFFICIENT TECHNIQUE TO CARRY OUT THE GIVEN OPERATION
}

\author{
BIELIKOV A. S. ${ }^{1}$, Dr. Sc. (Tech.), Prof.,
}

KREKNIN K. A. ${ }^{2}$, engineer,

STEKHNA P.M. ${ }^{3}$, teacher,

SHEVCHENKO A.V. ${ }^{4}$, master.

${ }^{1}$ Life and Safety Department, State Higher Educational Establishment «Pridneprovsk State Academy of Civil Engineering and Architecture», 24 , Chernishevskogo str., Dnipro, Ukraine, +38 (056) 756-34-73, e-mail: bgd@mail.pgasa.dp.ua, ORCID ID: 0000-0001-5822-9682

${ }^{2}$ Construction and Road Machines Department, State Higher Educational Establishment «Pridneprovsk State Academy of Civil Engineering and Architecture», 24 ${ }^{\mathrm{A}}$, Chernishevskogo str., Dnipro, Ukraine, +38 (056) 756-34-73, e-mail: kirmeh@gmail.com, ORCID ID: 0000-0002-1812-7400

${ }^{3}$ Foreign Languages Department, State Higher Educational Establishment «Pridneprovsk State Academy of Civil Engineering and Architecture», 24 ${ }^{\mathrm{A}}$, Chernishevskogo str., Dnipro, Ukraine, +38 (056) 756-34-73, e-mail: bgd@mail.pgasa.dp.ua

${ }^{4}$ Life and Safety Department, State Higher Educational Establishment «Pridneprovsk State Academy of Civil Engineering and Architecture»,24 ${ }^{\mathrm{A}}$, Chernishevskogo str., Dnipro, Ukraine, +38 (056) 756-34-73, e-mail: bgd@mail.pgasa.dp.ua

Summary. Problem statement. Lack of constant control after proper state of buildings and structures, inadequacy of operation of engineering equipment according to standards and regulations, as statistics shows, causes emergencies where damage of building structures occurs as a whole. The aim of research is the development of solutions concerning efficient renovation of transportation ways and establishment of driveways (passages) in obstructions and destruction areas. Conclusion. Carried out research on damage of buildings due to technogeneous events permitted to obtain the relations permitting prognostication of the character of formation of pieces in obstructions in adjoined areas and roads taking into account type and range of residential buildings.

Keywords: elimination of consequences of damages; increasing of safety

\section{ПІДВИЩЕННЯ БЕЗПЕКИ ПІД ЧАС ЛІКВІДАЦІЇ НАСЛІДКІВ РУЙНУВАНЬ НА ОБ'ЄКТАХ ТА ВИБІР НАЙБІЛЬШ ЕФЕКТИВНОЇ ТЕХНІКИ ДЛЯ ПРОВЕДЕННЯ ЦІЁ̈ ОПЕРАЦІї}

БСЛІКОВ А. С. ${ }^{1}$ д-р техн. наук, проф.,

КРЕКНІН К. А. ${ }^{2}$, інж.,

СТЕХНА П. М., викл.,

ШЕВЧЕНКО А. В. ${ }^{4}$, магістр

${ }^{1}$ Кафедра безпеки життєдіяльності, Державний вищий навчальний заклад «Придніпровська державна академія будівництва та архітектури», вул. Чернишевського, 24-a, 49600, Дніпро, Україна, +38 (056) 756-34-73, e-mail: bgd@mail.pgasa.dp.ua, ORCIDID: 0000-0001-5822-9682

${ }^{2}$ Кафедра будівельних і дорожніх машин, Державний вищий навчальний заклад «Придніпровська державна академія будівництва та архітектури», вул. Чернишевського, 24-a, 49600, Дніпро, Україна, +38 (056) 756-34-73, e-mail: kirmeh@gmail.com, ORCID ID: 0000-0002-1812-7400

${ }^{3}$ Кафедра іноземних мов, Державний вищий навчальний заклад «Придніпровська державна академія будівництва та архітектури», вул. Чернишевського, 24-a, 49600, Дніпро, Україна, +38 (056) 756-34-73, e-mail: bgd@mail.pgasa.dp.ua

${ }^{4}$ Кафедра безпеки життєдіяльності, Державний вищий навчальний заклад «Придніпровська державна академія будівництва та архітектури», вул. Чернишевського, 24-a, 49600, Дніпро, Україна, +38 (056) 756-34-73, e-mail: bgd@mail.pgasa.dp.ua

Анотація. Постановка проблеми. Відсутність постійного нагляду за належним станом будівель і споруд, невідповідність експлуатації технологічного обладнання згідно 3 нормами та правилами, як свідчить статистика, спричинюють виникнення надзвичайних ситуацій, за яких відбувається руйнування будівельних конструкцій та споруд у цілому. Мета досліджень - розроблення рішень з ефективного відновлення транспортних шляхів та влаштування проїздів (проходів) у завалах та в зонах руйнувань. Висновок. Дослідження руйнувань будівель у наслідок техногенних подій дозволили одержати залежності, які допомогають прогнозувати характер утворення уламків у завалах на прилеглих територіях та дорогах, 3 урахуванням типу та серії житлових будівель.

Ключові слова: ліквідація наслідків руйнувань; підвищення безпеки 


\title{
ПОВЫШЕНИЕ БЕЗОПАСНОСТИ ПРИ ЛИКВИДАЦИИ ПОСЛЕДСТВИЙ РАЗРУШЕНИЙ НА ОБЪЕКТАХ И ВЫБОР НАИБОЛЕЕ ЭФФЕКТИВНОЙ ТЕХНИКИ ДЛЯ ПРОВЕДЕНИЯ ДАННОЙ ОПЕРАЦИИ
}

\author{
БЕЛИКОВ А. С. ${ }^{1} \partial-р$ техн. наук, проф.,
}

КРЕКНИН К. А. ${ }_{3}$, инж.,

СТЕХНА П. М. ${ }^{3}$, npenod.,

ШЕВЧЕНКО А. В. ${ }^{4}$, магистр

${ }^{1}$ Кафедра безопасности жизнедеятельности, Государственное высшее учебное заведение «Приднепровская государственная академия строительства и архитектуры», ул. Чернышевского, 24-а, 49600, Днипро, Украина, +38 (056) 756-34-73, e-mail: bgd@mail.pgasa.dp.ua, ORCID ID: 0000-0001-5822-9682

${ }^{2}$ Кафедра строительных и дорожных машин, Государственное высшее учебное заведение «Приднепровская государственная академия строительства и архитектуры», ул. Чернышевского, 24-a, 49600, Днипро, Украина, +38 (056) 756-34-73, e-mail: kirmeh@gmail.com, ORCID ID: 0000-0002-1812-7400

${ }^{3}$ Кафедра иностранных языков, Государственное высшее учебное заведение «Приднепровская государственная академия строительства и архитектуры», ул. Чернышевского, 24-a, 49600, Днипро, Украина, +38 (056) 756-34-73, e-mail: bgd@mail.pgasa.dp.ua

${ }^{4}$ Кафедра безопасности жизнедеятельности, Государственное высшее учебное заведение «Приднепровская государственная академия строительства и архитектуры», ул. Чернышевского, 24-а, 49600, Днипро, Украина, +38 (056) 756-34-73, e-mail: bgd@mail.pgasa.dp.ua

Аннотация. Постановка проблемы. Отсутствие постоянного надзора за надлежащим состоянием зданий и сооружений, несоответствие эксплуатации технологического оборудования с нормами и правилами, как свидетельствует статистика, приводит к возникновению чрезвычайных ситуаций, при которых происходит разрушение строительных конструкций и сооружений в целом. Целью исследований является разработка решений по эффективному восстановлению транспортных путей и устройству проездов (проходов) в завалах и зонах разрушений. Вывод. Проведенные исследования разрушений зданий в результате техногенных событий позволили получить зависимости, помогающие прогнозировать характер образования обломков в завалах на прилегающих территориях и дорогах с учетом типа и серии жилых зданий.

Ключевые слова: ликвидация последствий разрушений; повышение безопасности

According to carried out analysis [2, 3], as a result of technogeneous accidents there may occur damages of buildings, structures, transportation ways causing obstructions, failures, fires and other unforeseen situations. Because of that, the actual problem is necessity of measures concerning elimination of consequences of emergencies, people saving and elimination of damages. Such measures are connected with the necessity of obstruction clearance of transportation networks for movement of machinery and rescue facilities.

The carried out analysis shows that investigations concerning safety and availability of rescue operations during emergencies have not been carried out in full measure.

The aim of research is the development of solutions concerning renovation of transportation ways and establishment of driveways (passages) in obstructions and destruction areas. For such works, it is reasonably to use mobile, versatile and multifunctional machinery.
Taking into account the life activity of injured people wrecking is executed in maximal short terms. Moreover, it should be considered the necessity to assist the injured timely medical aid as well as possible damages and losses which can be increased subsequently the influence of secondary striking factors (fire, explosions, floods etc.).

Buildings and structures can be destroyed and damaged as the result of the action of technogeneous catastrophes, natural phenomena, accidents and other emergencies.

According to carried out researches the causes of occurrence of technogeneous catastrophes and accidents connected with damage of buildings and structures are:

- Use violation of buildings and structures and service facilities;

- load increasing on buildings and structures exceeding standards and unforeseen influence on structures during their use $[1,2$, 3];

- reducing of strength of structural elements during use depending on various 
factors: moisture, temperature alternation, mechanical wear etc. $[4,5]$;

- low-quality construction and repair work, infringement of standards of execution as well as untimely repairing;

- casual handling with gas and electrical appliances.

An accident can occur in case of violation of project solutions and standard characteristics, manufacture of prefabricated goods, building erection. Sometimes buildings, their constructional elements and equipment can be damaged as the result of the effect of not only separate factor but their cumulative effects.

Damage of buildings can occur as the result of reducing the strength of structures of building projects, effect of mechanical wear particularly corrosion of joints of elements of reinforced concrete items and fatigue in building structures.

In Ukraine the most widespread natural phenomena are landslides, floods, hurricanes, whirlwinds. Their occurrence causes great damages of building projects.

Owing to the mentioned above, it is reasonably to consider the analysis of wrecking and recovery work during elimination of domestic gas explosions.

In some works [6,7] damage of building structures was investigated when the source of gas explosion is located on lower and middle storeys. Obtained results in all probability permit to prognosticate scale and character of damage of building structures, thus forming forces and facilities to eliminate consequences of emergencies. However, according to the analysis of accidents [8] recently very often gas explosions can occur on upper storeys of buildings destroying firstly roofs, upper service and living floors.

Besides, flying-off of pieces to the maximum that causes blocking of transportation facilities (roads). Lack of researches on the character of such damage does not permit to execute works efficiently and safely in full, that conditions baselessness of made solutions concerning organization and conduction of wrecking-recovery and repairbuilding work. Thus, in order to dismount and clear obstructions with the use of proper machinery it is necessary to study the character of damage in residential and industrial buildings connected with collapse of building structures on transportation facilities.

Presence of formed obstructions influences negatively on safety, operability and efficiency of execution of work.

According to International Labour Organization, it is found that longitudinal time of elimination of consequences of $\tau_{\mathrm{T}}$ is described with the help of Erlang distribution:

$$
\begin{aligned}
& \Phi\left(\tau_{\mathrm{T}}\right)=\frac{\left(\mu \cdot \tau_{T}\right)}{r} e^{-\mu \cdot \tau} ; \\
& (\tau>0 ; r=0,1,2 \ldots) ;
\end{aligned}
$$

where: $\mu$ - constant parameter;

$r$ - order of Erlang distribution.

At that, taking into consideration of probability if $\tau_{\mathrm{T}}$ is not less than $\tau$ (standard value) accordingly. Therefore, taking into account probability of risk $\varepsilon_{\text {н.p }}$ of execution of work outside the standard value of time $\tau_{H}$, one can determine the quantity of unforeseen works concerning dismounting of damages that will exceed the given time. Thus, if $\varepsilon_{\text {н.p. }}=0.1$ among ten cases for one longitudinal time of dismounting will exceed standard time $\tau_{\mathrm{H}}$;

$$
\mathrm{P}\left(\tau_{\mathrm{T}} \geq \tau_{\mathrm{H}}\right) \leq \varepsilon_{\text {н.p. }}
$$

Carried out analysis of elimination of consequences of emergencies shows that reducing of the value of risk of traumatizing of workers during dismounting structures causes increasing of time of elimination of consequences of emergencies.

While determining risk of the process of elimination of consequences of emergencies we accepted relation of determining the time of obstruction elimination and access to the object for main work execution according to the methods of risk determining of increase of the time of elimination of emergency:

$$
\tau_{\text {л.з }}=\tau_{\text {в.ч }}+\tau_{\text {в.о }}+\tau_{\text {o.i }}+\tau_{\text {з.е. } 3}+\tau_{c}+\tau_{p}+
$$

where $\tau_{\text {в.ч }}$ - time from the moment of emergency occurrence (according to references on evacuation and warning from 3 till $6 \mathrm{~min}$.);

$\tau_{\text {в.о }}$ - time from the moment of warning from governing services from 3 till $4 \mathrm{~min}$.; 

$\min$. );

$\tau_{\mathrm{o.i}}$ - time for processing information (till 1

$\tau_{\text {3.е. } 3}$ - time for making decisions, use of one or another forces or means $(3 \mathrm{~min}$. According to the Order of the Administration of Ministry of Internal Affairs of Ukraine № 325 of 01.07 .1993 and $1 \mathrm{~min}$. for gathering of personnel of special forces unit );

$\tau_{c}$ - time for movement to emergency unit (15 min. Regulation of the Cabinet of Ministers of Ukraine of 27.11.2013);

$\tau_{\text {л.з. }}$ - time for elimination of obstruction, dismounting of damage (which can be prognosticated taking into account the structure of emergency).

Time for movement to emergency unit depends in full on transportation of forces and means and movement routes.

Taking into account that after warning the head of special forces unit makes decision, time for movement and arrival of special forces unit depends on the choice of optimal (rational) movement route in local network. Taking into consideration carried out research in the city of Dnipro, there were studied possible movement routes for machinery to possible emergency units in residential area Peremoha in Dnipro. At the same time there were determined the conditions of elimination of possible obstructions in collapse of buildings and structures taking into account the use of machinery, in order to determine possible movement routes in Dnipro there was studied permanent location of special force units, machinery and special equipment. At the same time emergencies were considered that conditioned the decision to use one or another special units, machinery and equipment.

In order to determine rational (optimal) movement routes to emergency units, maps of traffic system were considered as well as city outlines of territorial division of Dnipro and service facilities in solving the problem on reducing loss of time of movement $\tau_{c}$ using theory of graphs.

In our research it was found that advanced approach in determining movement route and divisions of task performance into first priority and main priority permit as a whole to reduce arrival time of special units to emergency units providing traffic safety by $15-30 \%$ and increase the efficiency of operations. It is proved by research on determining movement time to emergency units by special units in order to perform first and main priority tasks taking into account their transportation to the place of emergency.

Concerning the time of prognostication of elimination of consequences of emergencies, it in full depends on engineering processes of dismounting of structures, obstructions and saving of wrecked.people. Therefore, it is necessary to investigate processes of dismounting of damage of structures using means of mechanization and defining the criteria of efficiency and safety of their execution.

On the base of the analysis of operations of elimination of consequences of emergencies connected with damage of buildings, structures and transportation networks and on the base of research on this problem it is offered to evaluate efficiency and safety of processes of dismounting of damage of structures and use of means of mechanization in following indexes and demands to them:

1. Duration $T_{P}$ of dismounting of obstruction should be minimal taking into account life and safety of the wrecked:

$$
T_{p}=\sum T_{i} \rightarrow \min ; T_{r} \leq T_{f}=6 . .120 \text { hours },
$$

where $_{\mathrm{i}}$ - duration of particular processes;

$\mathrm{T}_{\Phi}$ - time factor to dismount those parts of obstruction where possibly the wrecked can be found.

2. Average productivity $\Pi$ of work execution taking into account peculiarities of obstruction and safety of work execution:

$$
\Pi=\sum\left(\frac{V}{T_{p}}\right) \rightarrow \max ,
$$

where $\mathrm{V}$ - volume of executed obstruction.

3. Duration of operating cycle $\mathrm{T}_{\mathrm{L}} \mathrm{Of}$ means of mechanization in elimination of obstructions:

$$
T_{u}=\sum t_{\text {onp. } i} \rightarrow \min ,
$$

where $t_{\text {опр.i }}$ - duration of particular working operations of means of mechanization.

On the base of carried out theoretical research on elimination of consequences of 
emergencies connected with damage of buildings and structures criteria of efficiency and safety of dismounting of damage.

Carried out research on damage of buildings due to technogeneous events permitted to obtain the relations permitting prognostication of the character of formation of pieces in obstructions in adjoined areas and roads taking into account type and range of residential buildings and determine safety time to eliminate emergency.

\section{СПИСОК ВИКОРИСТАНИХ ДЖЕРЕЛ}

1. Болотин В.В. Применение методов теории вероятности и теории надежности в расчетах сооружений / В. В. Болотин. - Москва : Изд-во лит-ры по стр-ву, 1971. - 255 с.

2. Научные основы эффективного предупреждения и борьбы с чрезвычайными ситуациями и стихийными бедствиями : метод. рук. / М. В. Болотских, М. В. Орешкин, П. В. Шелихов, Е. П. Луганцев / Луган. нац. аграр. ун-т. - Луганск : ЛНАУ, 2004. .- 35 с.

3. Боровский Б. Техногенные аварии в системах газоснабжения и их предупреждение / Б. Боровский, Е. Лапина // Motrol. - 2009. - № 11A. - С. 120-122.

4. Венецкий И. Г. Основные математико-статистические понятия и формулы в экономическом анализе. Справочник / И. Г. Венецкий, В. И. Венецкая. - 2-е изд., перераб. и доп. - Москва : Статистика, 1979. 447 с. - (Мат. статистика для экономистов).

5. Голов Г. И. Демонтажные работы при реконструкции зданий / Голов Г. И. - Москва : Стройиздат. - 1990. $143 \mathrm{c}$.

6. Гончаренко Д. Ф. Ремонт и восстановление канализационных сетей и сооружений / Д. Ф. Гончаренко, И. В. Коринько. - Харьков : Рубикон, 1999. - 365 с.

7. Строительство и реконструкция стадионов : [монографія] / Д. Ф. Гончаренко, С. М. Евель, Г. Г. Зубко, О. В. Старкова. - Харьков : Колорит, 2013. - 352 с.

8. Гончаренко Д. Ф. Технология демонтажных и строительно-монтажных работ при восстановлении частично разрушенного здания / Д. Ф. Гончаренко, Н. А. Меленцов, А. С. Константинов // Промислове будівництво та інженерні споруди. - 2013. - № 1. - С. 42-44.

\section{REFERENCES}

1. Bolotin V.V. Primenenie metodov teorii veroyatnosti $i$ teorii nadezhnosti v raschetax sooruzhenij [The application of probability theory methods and reliability theory in the structures calculation]. Moskva: Izd-vo lit-ry po str-vu, 1971, 255 p. (in Russian).

2. Bolockix M.V., Oreshkin M.V., Shelixov P.V. and Lugancev E.P. Nauchnye osnovy effektivnogo preduprezhdeniya $i$ bor'by s chrezvychaynymi situatsiyami i stixijnymi bedstviyami [Scientific foundations for effective prevention and control of emergencies and natural disasters]. Lugan. nac. agrar. un-t. [Lugansk National Agrarian Universiry]. Lugansk: LNAU, 2004, 35 p. (in Russian).

3. Borovski B. and Lapina E. Texnogennye avarii v sistemax gazosnabzheniya i ix preduprezhdenie [Technogenic accidents in gas supply systems and their prevention]. Motrol [Motrol]. 2009, no. 11A, pp. 120-122. (in Russian).

4. Venetskij I.G. and Venetskaya V.I. Osnovnye matematiko-statisticheskie ponyatiya i formuly $v$ ekonomicheskom analize [Basic mathematical and statistical concepts and formulas in economic analysis.]. Mat. statistika dlya ekonomistov [Mathematical statistics for economists]. Ed. 2, Moskva: Statistika, 1979, 447 p. (in Russian).

5. Golov G.I. Demontazhnye raboty pri rekonstrukcii zdanij [Dismantling work in the buildings reconstruction]. Moskva: Strojizdat, 1990, 143 p. (in Russian).

6. Goncharenko D.F. and Korin'ko V.I. Remont $i$ vosstanovlenie kanalizatsionnyx setej $i$ sooruzhenij [Repair and restoration of sewer networks and structures]. Xar'kov: Rubikon, 1999, 365 p. (in Russian).

7. Goncharenko D.F. Evel' S.M., Zubko S.M. and Starkova O.V. Stroitel'stvo i rekonstrukciya stadionov [Construction and reconstruction of stadiums]. Xar'kov: Kolorit, 2013, 352 p. (in Russian).

8. Goncharenko D.F. Melentsov N.A. and Konstantinov A.S. Texnologiya demontazhnyx i stroitel'no-montazhnyx rabot pri vosstanovlenii chastichno razrushennogo zdaniya [Technology of dismantling, construction and installation works for the restoration of a partially destroyed building]. Promyslove budivnitstvo ta inzhenerni sporudy [Industrial construction and engineering structures]. 2013, no. 1, pp. 42-44. (in Russian).

Рецензент: Шатов С. В., д-р техн. наук, проф.

Надійшла до редколегії: 17.01.2018 p. 